
A
$\mathbf{R}$
$\mathbf{T}$
$\mathbf{Y}$
$\mathbf{K}$
$\mathrm{U}$
$\mathbf{E}$

Agata Kleczkowska

Polska Akademia Nauk

\title{
IDENTYFIKACJA MIĘDZYNARODOWEGO PRAWA ZWYCZAJOWEGO W OPINII DORADCZEJ MIĘDZYNARODOWEGO TRYBUNAŁU SPRAWIEDLIWOŚCI W SPRAWIE ARCHIPELAGU CZAGOS
}

\section{WSTĘP}

25 lutego 2019 r. Międzynarodowy Trybunał Sprawiedliwości (MTS) wydał opinię doradczą dotyczącą prawnych konsekwencji oddzielenia archipelagu Czagos od Mauritiusa w 1965 r. ${ }^{1}$ Postępowanie przed MTS zostało wszczęte $\mathrm{w}$ związku $\mathrm{z}$ dwoma pytaniami zadanymi Trybunałowi przez Zgromadzenie Ogólne ONZ (ZO ONZ) w rezolucji 71/292², które dotyczyły procesu dekolonizacji Mauritiusa, legalności oddzielenia od Mauritiusa archipelagu Czagos i prawnych konsekwencji nieprzerwanego sprawowania przez Wielką Brytanię administracji nad archipelagiem.

1 Legal Consequences of the Separation of the Chagos Archipelago from Mauritius in 1965, Opinia doradcza z 25 lutego 2019 r., ICJ Reports 2019, s. 1 (dalej: opinia doradcza ws. archipelagu Czagos)

2 Rezolucja ZO ONZ 71/292 „Request for an advisory opinion of the International Court of Justice on the legal consequences of the separation of the Chagos Archipelago from Mauritius in $1965^{\prime \prime} \mathrm{z} 22$ czerwca 2017 r., A/RES/71/292. 
Od 1814 r. archipelag Czagos był administrowany przez Wielką Brytanię, jako terytorium zależne Mauritiusa, który był wówczas kolonią brytyjską. Z dokumentów przywołanych przez MTS wynika jednoznacznie, że Mauritius i archipelag Czagos traktowane były jako jeden organizm. W 1964 r. Stany Zjednoczone wyraziły zainteresowane budową instalacji wojskowej na jednej z wysp archipelagu Czagos. W związku z tym w czerwcu tego samego roku Wielka Brytania rozpoczęła rozmowy z przedstawicielami Mauritiusa dotyczące odłączenia archipelagu Czagos od Mauritiusa. Do podpisania umowy w tej sprawie, tzw. Lancaster House agreement, doszło we wrześniu 1965 r. Dwa miesiące później Wielka Brytania ustanowiła nową kolonię, Brytyjskie Terytorium Oceanu Spokojnego (British Indian Ocean Territory), składającą się $z$ archipelagu Czagos i trzech wysp oddzielonych od Seszeli. W kolejnym roku Stany Zjednoczone i Wielka Brytania podpisały umowę o wykorzystaniu przez USA archipelagu Czagos, która przewidywała m.in. przesiedlenie lokalnej ludności. Kiedy 12 marca 1968 r. Mauritius stał się niepodległym państwem, jego terytorium nie obejmowało archipelagu Czagos. Już od 1980 r. jednak zarówno Mauritius, jak i Organizacja Jedności Afrykańskiej (a potem Unia Afrykańska), zaczęły podnosić, że odłączenie archipelagu Czagos od Mauritiusa było niezgodne z prawem międzynarodowym.

Aby rozstrzygnąć pojawiające się $\mathrm{w}$ sprawie problemy prawne związane $z$ dekolonizacją i prawem do samostanowienia ${ }^{3}$, Trybunał zbadał kształt norm międzynarodowego prawa zwyczajowego dotyczących prawa do samostanowienia w okresie dekolonizacji. Rozważania Trybunału co do sposobu formowania się norm prawa zwyczajowego

\footnotetext{
Ostatecznie MTS doszedł do wniosku, że proces dekolonizacji Mauritiusa nie został ukończony zgodnie z prawem, a kontynuując sprawowanie administracji nad archipelagiem Czagos, Wielka Brytania popełniła czyn międzynarodowo bezprawny. W związku z tym ma ona obowiązek jak najszybciej zakończyć sprawowanie administracji nad archipelagiem. Ustalenia te potwierdziło Zgromadzenie Ogólne ONZ w rezolucji 73/295 „Advisory opinion of the International Court of Justice on the legal consequences of the separation of the Chagos Archipelago from Mauritius in 1965" z 22 maja 2019 r., która dodatkowo m.in. wezwała wszystkie organizacje międzynarodowe do uznania archipelagu Czagos za część Mauritiusa.
} 
odgrywają więc kluczową rolę w rozstrzygnięciu Trybunału, ponieważ pozwoliły mu ustalić stan prawny konieczny dla orzeczenia o odpowiedzialności Wielkiej Brytanii.

Celem niniejszego artykułu jest przeanalizowanie metodologii, za pomocą której MTS dokonał identyfikacji norm międzynarodowego prawa zwyczajowego odnoszących się do samostanowienia. Przedmiotem badania będzie więc czwarta część opinii doradczej, „Pytania zadane Trybunałowi przez Zgromadzenia Ogólne”, z odwołaniem się do pozostałych fragmentów opinii, które mogą mieć znaczenie dla ustalenia sposobu identyfikacji zwyczaju przez Trybunał. Artykuł opiera się na tezie, że metodologia identyfikacji zwyczaju, zastosowana przez Trybunał, jest nieprzekonująca, ponieważ MTS niedostatecznie zbadał proces kształtowania się normy prawa zwyczajowego regulującej prawo do samostanowienia, co z kolei podważa zasadność całego rozstrzygnięcia Trybunału, bowiem chodzi o normę będącą podstawą wyrokowania przez MTS w omawianej sprawie.

Artykuł został podzielony na cztery części: pierwsza przedstawia zwięźle najważniejsze wątki rozważań Trybunału co do prawa zwyczajowego. W drugiej części porównano dotychczasową metodologię MTS, jeśli chodzi o identyfikację zwyczaju, z rozważaniami z opinii doradczej ws. archipelagu Czagos. W trzeciej części omówiono to, jak Trybunał przedstawił w opinii doradczej sposób formowania się zwyczaju. Czwarta część została natomiast poświęcona rezolucji ZO ONZ 1514.

\section{RozwaŻania TrybunaŁu dotycząCE PRAWA ZWyCZajowego}

Najważniejszą częścią opinii doradczej jest rozdział pt. „Pytania zadane Trybunałowi przez Zgromadzenie Ogólne”, który, jak wskazuje sam tytuł, zawiera odpowiedzi na pytania zadane MTS przez ZO ONZ. W podrozdziale A, MTS badał czy proces dekolonizacji Mauritiusa został zakończony zgodnie z prawem międzynarodowym. W tym celu Trybunał ustalił najpierw, że choć pytania ZO ONZ odnoszą się do wydarzeń, które miały miejsce między 1965 r. a 1968 r., nie stoi to na przeszkodzie, aby Trybunał, w szczególności w zakresie norm prawa 
zwyczajowego, zbadał ewolucję prawa do samostanowienia od czasu przyjęcia Karty Narodów Zjednoczonych (KNZ) i rezolucji 15144. Trybunał uznał, że taki zabieg jest konieczny, ponieważ, praktyka i opinio iuris państw „utrwalają się i potwierdzają stopniowo” w miarę upływu czasu.

Następnie MTS przeszedł do ustalenia prawa właściwego do rozstrzygnięcia sprawy, tj. „charakteru, treści i zakresu” prawa do samostanowienia, które miało mieć zastosowanie do procesu dekolonizacji Mauritiusa, tak jak było ono obecne w praktyce ONZ, jak i władzy administrującej (czyli Wielkiej Brytanii) od 1946 r. i w późniejszym okresie. Swoją analizę MTS zaczął od przywołania fragmentu art. 1 ust. 2 KNZ, z którego wynika, że poszanowanie zasady równouprawnienia i samostanowienia narodów jest jednym z celów Narodów Zjednoczonych ${ }^{5}$. Cel ten realizowany jest zwłaszcza w „Deklaracji w sprawie terytoriów niesamodzielnych", zawartej w Rozdziale XI Karty, a w szczególności w art. 73. Na tej podstawie Trybunał stwierdził, że Karta zawiera postanowienia, które mają ostatecznie umożliwić niesamodzielnym terytoriom pełny samorząd w przyszłości. Trybunał doszedł do wniosku, że „właśnie w tym kontekście (...) musi ustalić kiedy prawo do samostanowienia wykrystalizowało się jako norma prawa zwyczajowego wiążąca wszystkie państwa”.

Trybunał przywołał dalej treść art. 38 Statutu MTS, zgodnie z którym zwyczaj stanowi „powszechna praktyka uznana za prawo”. Stwierdził, że oba elementy, tj. i praktyka i opinio iuris, mają znaczenie dla tworzenia się zwyczaju i są blisko związane, na dowód czego powołał fragment wyroku w sprawie Szelfu Kontynentalnego Morza Północnego ${ }^{6}$.

Trybunał uznał, że krytycznym momentem dla konsolidacji praktyki państw dotyczącej dekolonizacji było przyjęcie rezolucji ZO ONZ 1514. Zanim do tego doszło, ZO ONZ potwierdzało znaczenie prawa

4 Rezolucja ZO ONZ 1514 „Declaration on the Granting of Independence to Colonial Countries and Peoples” z 16 grudnia 1960 r., A/RES/1514.

5 Karta Narodów Zjednoczonych, Statut Międzynarodowego Trybunału Sprawiedliwości i Porozumienie ustanawiające Komisję Przygotowawczą Narodów Zjednoczonych, Dz. U. z 1947 r. Nr 23, poz. 90.

6 North Sea Continental Shelf, wyrok z 20 lutego 1969 r., ICJ Reports 1969, s. 44, par. 77 (dalej: Wyrok w sprawie North Sea Continental Shelf). 
do samostanowienia w kilku rezolucjach, tj. 637 (VII) z 16 grudnia 1952, 738 (VIII) z 28 listopada 1953 i 1188 (XII) z 11 grudnia 1957 r. To jednak dopiero rezolucja 1514 wyjaśniła znaczenie i zakres prawa do samostanowienia. Proces dekolonizacji przyspieszył w 1960 r., kiedy to 18 państw uzyskało niepodległość, a przez następną dekadę - kolejnych 28. Zdaniem Trybunału, istnieje wyraźny związek między rezolucją 1514 i przebiegiem dekolonizacji po jej przyjęciu.

Następnie Trybunał przywołał fragment opinii doradczej ws. groźby lub użycia broni nuklearnej, w którym wskazywał na wartość normatywną rezolucji ZO ONZ oraz to, że w pewnych okolicznościach, mogą być one ważnym dowodem istnienia zasady lub powstania opinio iuris ${ }^{7}$. Aby sprawdzić, czy tak jest, należy zbadać zakres i okoliczności przyjęcia rezolucji oraz to, czy istnieje opinio iuris co do normatywnego charakteru rezolucji. Korzystając z tych ustaleń, Trybunał stwierdził, że choć rezolucja 1514 jest formalnie jedynie rekomendacją, to ma charakter deklaratoryjny w stosunku do prawa do samostanowienia jako normy prawa zwyczajowego. Jeśli chodzi o okoliczności jej uchwalenia, rezolucja 1514 została przyjęta 89 głosami za, żadne państwo nie głosowało przeciw, a 9 wstrzymało się od głosu ${ }^{8}$. Żadne z państw nie zakwestionowało jednak istnienia prawa do samostanowienia, a niektóre $\mathrm{z}$ państw wstrzymujących się od głosu uzasadniały swoją decyzję tym, że potrzeba czasu dla implementacji tego uprawnienia.

Jeśli chodzi o treść rezolucji, sformułowania użyte w niej mają charakter normatywny. Dla uzasadnienia tego, Trybunał przytoczył kilka fragmentów rezolucji, w tym: „wszystkie ludy mają prawo do samostanowienia”; istnieje „konieczność szybkiego i bezwarunkowego zakończenia kolonializmu we wszystkich jego formach i przejawach" oraz „jakakolwiek próba zaburzenia, częściowego lub całkowitego, jedności państwowej i integralności terytorialnej państwa jest niezgodna z celami i zasadami Karty Narodów Zjednoczonych”.

7 Legality of the Threat or Use of Nuclear Weapons, opinia doradcza z 6 lipca 1996 r., ICJ Reports 1996, s. 226, par. 70.

8 Były to: Australia, Belgia, Republika Dominikany, Francja, Portugalia, Hiszpania, Unia Afryki Południowej, Wielka Brytania i USA. 
Dalej, MTS powołał się na art. 1 wspólny Międzynarodowym Paktom Praw Człowieka ${ }^{9}$, który potwierdza prawo do samostanowienia i stwierdza, że strony Paktów mają obowiązek realizacji i poszanowania prawa do samostanowienia, zgodnie z KNZ. Natura i zakres prawa do samostanowienia zostały uznane także w Deklaracji zasad prawa międzynarodowego z rezolucji ZO ONZ 2625, natomiast sposób implementacji tego uprawnienia został określony w rezolucji ZO ONZ 1541 z 15 grudnia $1960 \mathrm{r}$.

Trybunał zwrócił także uwagę, że niektórzy uczestnicy postępowania wskazywali, że status prawa do samostanowienia jako normy prawa zwyczajowego nie pociągał za sobą obowiązku implementacji tego prawa w granicach niesamodzielnego terytorium. W tym kontekście MTS przypomniał, że prawo do samostanowienia jest definiowane w odniesieniu do całości niesamodzielnego terytorium, a zarówno praktyka, jak i opinio iuris państw w badanym okresie potwierdzają obowiązywanie prawa do integralności terytorialnej niesamodzielnego terytorium na gruncie prawa zwyczajowego, jako pochodnego prawu do samostanowienia.

Podsumowując, Trybunał stwierdził, że prawo do samostanowienia ma zastosowanie do badanego okresu.

Powyższe streszczenie stanowi całość rozważań Trybunału nad krystalizowaniem się norm prawa zwyczajowego regulujących samostanowienie.

\section{Metodologia MTS w OPINII DORAdCZEJ} WS. ARCHIPELAGU CZagos

Jak wynika z powyższego, MTS, chcąc zidentyfikować normę prawa zwyczajowego, która miała mu posłużyć za podstawę rozstrzygnięcia o odpowiedzialności Wielkiej Brytanii, nie dokonał w ogóle szczegółowej analizy praktyki i opinio iuris państw, ale posłużył się jedynie

9 Por. np. Międzynarodowy Pakt Praw Obywatelskich i Politycznych otwarty do podpisu w Nowym Jorku 19 grudnia 1966 r., Dz. U. z 1977 r. Nr 38, poz. 167. 
rezolucjami ZO ONZ, na poparcie roli których przytoczył dwa fragmenty swoich wcześniejszych decyzji.

To, że MTS nie zajął się szczegółową analizą praktyki i opinio iuris państw nie jest niczym nowym w orzecznictwie Trybunału. Część autorów od dawna wskazuje na specyficzną metodologię Trybunału, która pozwala mu uniknąć analizy całej praktyki i opinio iuris państw ${ }^{10}$. Najczęściej wskazywanymi metodami, którymi ma posługiwać się Trybunał są metody indukcyjna i dedukcyjna. Metoda indukcyjna ${ }^{11}$ polega na wyinterpretowaniu ogólnej normy z pojedynczych przykładów praktyki i opinio iuris państw, które są „empirycznie doświadczalne”, czyli polega na interpretowaniu od szczegółu do ogółu. Metoda dedukcyjna ${ }^{12}$ polega z kolei na przejściu od ogółu do szczegółu, tj. wyinterpretowaniu konkretnej normy z istniejącej już i powszechnie akceptowanej zasady lub normy ${ }^{13}$. Prawdą jest jednak też, na co wskazuje m.in. S. Talmon, że proces identyfikacji norm międzynarodowego prawa zwyczajowego przez Trybunał często polega po prostu na „stwierdzeniu” istnienia danej normy prawa zwyczajowego ${ }^{14}$.

10 Por. także F.E. Kirgis, Custom on a Sliding Scale, "American Journal of International Law» 81/1987, s. 147-148; B. Simma, P. Alston, The Sources of Human Rights Law: Custom, Jus Cogens and General Principles, «Australian Yearbook on International Law» 12/1988-89, s. 88.

11 MTS posłużył się tą metodą np. w Delimitation of the Maritime Boundary in the Gulf of Maine Area (Canada/United States of America), wyrok z 12 października 1984, ICJ Reports 1984, s. 246, par. 111; Jurisdictional Immunities of the State (Germany v. Italy: Greece intervening), wyrok z 3 lutego 2012 r., ICJ Reports 2012, s. 99, par. 57 (dalej: wyrok w sprawie Jurisdictional Immunities of the State).

12 Metoda ta została wykorzystana przez MTS w sprawie Wyroku w sprawie North Sea Continental Shelf, par. 3; Arrest Warrant of 11 April 2000 (Democratic Republic of the Congo v. Belgium), wyrok z 14 lutego 2012 r., ICJ Reports 2002, s. 3, par. 58.

13 S. TAlmon, Determining Customary International Law: The ICJ's Methodology between Induction, Deduction and Assertion, «The European Journal of International Law» 26.2/2015, s. 420-422; A. Alvarez-Jimbnez, Methods for the Identification of Customary International Law in the International Court of Justice's New Millennium Jurisprudence, «International and Comparative Law Quaterly» 60/2011, s. 686; A. RoBERTS, Traditional and Modern Approaches to Customary International Law: A Reconciliation, «American Journal of International Law» 95/2001, s. 758.

14 S. Talmon, op. cit., s. 434. Por. np. Wyrok w sprawie Nikaragui, par. 212. 
Tym, co jest szczególnie pomocne dla MTS przy korzystaniu z tych metod identyfikacji zwyczaju, jest posługiwanie się wcześniejszym orzecznictwem, wielostronnymi traktatami i rezolucjami organów ONZ ${ }^{15}$. P. Tomka wskazuje, że w ten sposób Trybunał wykorzystuje normy „wyraźnie sformułowane na piśmie” jako punkt odniesienia do zbadania zwyczaju, ponieważ forma pisemna pozwala na precyzyjne wyrażanie poglądów prawnych co ma przełożenie właśnie na sposób identyfikacji przez Trybunał zwyczaju ${ }^{16}$. Ze strony czysto pragmatycznej, nie sposób nie zauważyć także, że korzystanie z rezolucji czy traktatów jest mniej pracochłonne i łatwiej zbadać skutek prawny rezolucji czy traktatów niż wszystkie przejawy praktyki i opinio iuris państw ${ }^{17}$.

15 Р. Tомка, Custom and the International Court of Justice, «Law \& Practice of International Courts \& Tribunals» 12/2013, s. 215; K. SKUBISZEWSKI, Elements of custom and the Hague Court, «Zeitschrift für ausländisches öffentliches Recht und Völkerrecht» 31/1971, s. 829-830; A. D’AmAтo, Trashing Customary International Law, «The American Journal of International Law» 81/1987, s. 102; R. H. GEIGER, Customary International Law in the Jurisprudence of the International Court of Justice: A Critical Appraisal, [w:] From Bilateralism to Community Interest: Essays in Honourofjudge Bruno Simma, red. U. Fastenrath et al., Oxford 2011, s. 676-677. Por. np. Nottebohm Case (second phase), wyrok z 6 kwietnia 1955 r., ICJ Reports 1955, s. 4, s. 23; Fisheries Jurisdiction (United Kingdom v. Iceland), wyrok z 25 lipca 1974 r., ICJ Reports 1974, s. 3, par. 52; Opinia doradcza w sprawie groźby lub użycia broni nuklearnej, par. 70, 82; Wyrok w sprawie Jurisdictional Immunities of the State, par. 54; Militarv and Paramilitary Activities in und against Nicaragua (Nicaragua v. United States of America), wyrok z 27 czerwca 1986 r., ICJ Reports 1986, s. 14, par. 188 (dalej: Wyrok w sprawie Nicaragui).

16 P. Томка, op. cit., s. 196-198.

17 R. Higgins, Problems and Process: International Law and How We Use It, Oxford 1995, s. 24; J. Wouters, P. DE MAN, International organizations as law-makers, [w:] Research Handbook on the Law of International Organizations, red. J. KLABBERs, A. Wallendahl, Cheltenham/Northampton 2011, s. 208. Podobnie, poprzednim orzeczeniom MTS można postawić zarzut lakoniczności, a także dosyć arbitralnego doboru materiałów istotnych dla identyfikacji zwyczaju. Przykładowo, w sprawie prawa przejścia przez Indyjskie Terytorium, MTS badając normy prawne regulujące stosunki między stronami sporu, odwołał się jedynie do praktyki ustanowionej między stronami, nie badając opinio iuris (Case concerning Right of Passage over Indian Territory (Merits), wyrok z 12 kwietnia 1960 r., ICJ Reports 1960, s. 6, s. 43-44 (dalej: Wyrok w sprawie Right of Passage over Indian Territory). Z kolei w sprawie Nikaragui Trybunał uznał, że norma prawa zwyczajowego zakazująca użycia siły pokrywa się 
Czym w takim razie różni się opinia doradcza ws. archipelagu Czagos od poprzednich decyzji MTS, kiedy Trybunał korzystał z podobnej metodologii? Kilka kwestii zasługuje na szczególną uwagę. Po pierwsze, Trybunał zbadał jedynie opinio iuris, a nie nawiązał w ogóle do praktyki relewantnej dla powstania normy prawa zwyczajowego dotyczącej prawa do samostanowienia. Po drugie, Trybunał swoje rozstrzygnięcie w sprawie oparł na normie prawa zwyczajowego, zidentyfikowanej de facto jedynie na podstawie rezolucji ZO ONZ, nie popierając swojej analizy badaniem praktyki państw. Po trzecie, Trybunał wyraźnie przypisał rezolucjom ZO ONZ szczególne znaczenie, nie jako aktom pochodzącym od państw, ale od organizacji międzynarodowej, co nakazuje zastanowić się z tej perspektywy nad rolą aktów organizacji międzynarodowych $\mathrm{w}$ procesie formowania się norm powszechnego prawa zwyczajowego. Po czwarte, w odniesieniu do rezolucji 1514, której Trybunał nadał szczególne znaczenie, należy zweryfikować lakoniczną wypowiedź Trybunału co do jej znaczenia, w zakresie głosowania nad nią, postawy państw, które wstrzymały się od głosu oraz jej treści. Problemy te zostały zbadane w dalszej części artykułu.

\section{FORMOWANIE SIĘ NORM MIĘDZYNARODOWEGO PRAWA ZWYCZAJOWEGO W OPINII DORADCZEJ DOTYCZĄCEJ ARCHIPELAGU CZagos}

\subsection{Elementy normy prawa zwyczajowego}

Na wstępie rozważań co do identyfikacji zwyczaju Trybunał podtrzymał pogląd, że należy zbadać zarówno praktykę, jak i opinio iuris;

\footnotetext{
z treścią art. 2 ust. 4 KNZ oraz określił szczegółowe obowiązki wynikające z zakazu. Zrobił to jednak nie odwołując się do praktyki państw; stwierdził jedynie, że obie strony sporu są jednocześnie stronami KNZ, po czym zajął się analizą opinio iuris, które znalazł przede wszystkim w rezolucjach ZO ONZ i Organizacji Państw Amerykańskich. W tym samym wyroku MTS, zajmując się zasadą nieinterwencji w prawie zwyczajowym, po stwierdzeniu, że ta zasada jest normą prawa zwyczajowego, zbadał praktykę państw, ale jedynie pod tym kątem, czy nie istnieje norma pozwalająca państwom na interwencję dla wsparcia sił rebelianckich (F.E. KIRGIs, op. cit., s. 147).
} 
w swojej dalszej analizie Trybunał pominął jednak zupełnie pierwszy z tych elementów ${ }^{18}$. Rozpoczynając bowiem badanie normy prawa zwyczajowego, Trybunał powołał się na fragmenty swoich dwóch wcześniejszych decyzji - wyroku w sprawie Szelfu Kontynentalnego Morza Północnego i opinii doradczej w sprawie groźby lub użycia broni nuklearnej - z których pierwsza podkreślała znaczenie opinio iuris w procesie formowania się zwyczaju, a druga wskazywała, że rezolucje ZO ONZ mogą stanowić dowodów właśnie opinio iuris ${ }^{19}$. W dalszej części opinii MTS przeanalizował wyłącznie rezolucje ZO ONZ, z jednym wyjątkiem - między analizą rezolucji 1514 i pozostałych rezolucji ZO ONZ, powołał się na art. 1 Międzynarodowych Paktów Praw Człowieka. Z treści opinii doradczej nie wynika jednak, czy art. 1 Paktów był dla Trybunału dowodem praktyki czy opinio iuris. Co więcej, z kontekstu, w jakim artykuł ten został przywołany można wywnioskować, że miał posłużyć Trybunałowi jedynie dla wsparcia znaczenia postanowień rezolucji 1514 i pokazania, że zasady w niej zawarte zostały następnie przyjęte przez państwa jako wiążące normy w traktacie. Podsumowując, $\mathrm{w}$ analizie formowania się normy prawa zwyczajowego Trybunał zbadał de facto jedynie opinio iuris, pomijając relewantną praktykę.

W dalszej kolejności należy przyjrzeć się rezolucjom jako aktom relewantnym z punktu widzenia formowania się zwyczaju.

18 Na to, że ważne jest zbadanie obu elementów MTS zwracał także uwagę m.in. w wyroku w sprawie Nikaragui, par. 184.

19 Taki pogląd zresztą był wyrażany przez MTS wcześniej również w innych orzeczeniach, w tym m.in. w wyroku w sprawie działań militarnych i paramilitarnych w i przeciwko Nikaragui (Wyrok w sprawie Nikaragui, par. 207) oraz Szelfu Kontynentalnego (Libia przeciwko Malcie) (Continental Shelf (Libyan Arab Jarnahiriya/ Malta), wyrok z 3 czerwca 1995 r., ICJ Reports 1985, s. 13, par. 27). 
4.2. Rezolucje w procesie formowania się międzynarodowego prawa zwyczajowego

Na wstępie należy zauważyć, że ani w doktrynie ${ }^{20}$, ani w orzecznictwie $\mathrm{MTS}^{21}$ nie ma zgody co do tego, czy rezolucje stanowią dowód praktyki czy opinio iuris w procesie formowania się zwyczaju; niezależnie jednak od tego, należy stwierdzić, że rezolucje organizacji międzynarodowych, a w szczególności rezolucje ZO ONZ, mają znaczenie dla formowania się zwyczaju $^{22}$. Należy więc zapytać jakie znaczenie nadał MTS rezolucjom ZO ONZ w omawianej opinii doradczej.

Po pierwsze, nawet autorzy skłonni przypisać rezolucjom ZO ONZ szczególne znaczenie w procesie identyfikacji zwyczaju zauważają, że aby takie rezolucje przyczyniły się do powstania normy prawa zwyczajowego, musi im towarzyszyć praktyka państw, która potwierdzałaby, że państwa

20 T. RuYs, "Armed attack" and Article 51 of the UN Charter: customary law and practice, Cambridge 2010, s. 49; G. M. DANILENKo, The Theory of International Customary Law, "German Yearbook of International Law» 31/1988, s. 26; K. SkUBIszewski, The Elaboration of General Multilateral Conventions and of Non-Contractual Instruments Having a Normative Function or Objective, «Institute of International Law Yearbook» 61.I/1985, Session of Helsinki, s. 92-93. Por. także Letter dated 29 August 1980 from the Chairman of the Group of 77 to the President of the Conference, 23 September 1965, A/CONF.62/106, s. 112; International Law Association, Committee on Formation of Customary (General) International Law, Final Report of the Committee, Statement of Principles Applicable to the Formation of General Customary International Law, London Conference (2000), s. 60 (dalej: ILA Final Report); R. Higgins, op. cit., s. 23; I. Brownlie, The Rule of Law in International Affairs: International Law at the Fiftieth Anniversary of the United Nations, Haga 1998, s. 19-20; INTERNATIONAL LAw COMMIsSION, Second report on identification of customary international law by Michael Wood, Special Rapporteur, A/CN.4/672, par. 76g.

${ }^{21}$ Wyrok w sprawie Right of Passage over Indian Territory, s. 43-44; H.C.M. Charlesworth, Customary international law and the Nicaragua case, "Australian Yearbook of International Law» 11/1984-1987 s. 18, 28; K. SkubIszewsKi, The Elaboration of General..., s. 93-94.

22 Por. G. D. Kyriakopoulos, Formation of International Custom and the Role of Non-State Actors, [w:] Reconceptualising the Rule of Law in Global Governance, Resources, Investment and Trade, red. Ph. Pazartzis, M. Gavouneli, Oxford 2016, s. 48. Por. także International Law Commission, Third report on identification of customary international law by Michael Wood, Special Rapporteur, A/CN.4/682, par. 73. 
uważają postanowienia rezolucji za wiążące ich zasady postępowania na gruncie prawa międzynarodowego ${ }^{23}$. W przeciwnym wypadku, gdyby samo przyjęcie rezolucji (a nawet serii rezolucji) mogło doprowadzić do powstania normy prawa zwyczajowego, oznaczałoby to, że ZO ONZ ma kompetencje prawotwórcze, co więcej w odniesieniu do powszechnych norm prawa międzynarodowego, a więc może je narzucić także państwom nieczłonkowskim ONZ. Tymczasem ani KNZ, ani państwa w swojej praktyce, nie nadały ZO ONZ takich kompetencji ${ }^{24}$. W sprawie archipelagu Czagos, MTS w ogóle nie zajął się analizą praktyki państw, która potwierdzałaby stanowisko zajęte przez państwa w rezolucji 1514 $\mathrm{i}$ innych dotyczących prawa do samostanowienia i dekolonizacji.

Po drugie, MTS powołał się na serię rezolucji ZO ONZ, które dotyczyły prawa do samostanowienia i potwierdzały te same zasady. Taka powtarzalność zdaniem Trybunału stanowi ważny argument za tym,

23 M. H. Mendelson, The Formation of Customary International Law, «Recueil de cours» 272/1998, s. 387; K. Skubiszewski, The Elaboration of General..., s. 118, 237; P. TomкA, op. cit., s. 211; R. Higgins, op. cit., s. 28; R. BAKeR, Legal Recursivity and International Law: Rethinking The Customary Element, «The Dartmouth Law Journal» 14/2016, s. 11-12; T. Ruys, op. cit., s. 50; B. SCHLÜTTER, Developments in Customary International Law, Leiden/Boston 2010, s. 275-276; wypowiedź A. Cassese w czasie debaty podczas kolokwium, które odbyło się na European University Institute we Florencji, red. A. Cassesse, J.H.H. Weiler, Change and stability in international law-making, Berlin 1988, s. 24. Podobny pogląd wyraża również część państw - por. stanowiska Wielkiej Brytanii (Written Reply of the United Kingdom to the question put by Judge Cançado Trindade at the end of the hearing held on 5 September 2018, 10 September 2018, par. 4, https://www.icj-cij.org/files/case-related/169/169-20180910-OTH-02-00-EN.pdf (dostęp 15 sierpnia 2019 r.), Australii - UN GA Official Records, Sixth Committee, 21st meeting, 25 October 2016, A/C.6/71/SR.21, par. 18), Nowej Zelandii (Comments by the Government of New Zealand, 21 December 2017, s. 24, http://legal.un.org/docs/?path=../ ilc/sessions/70/pdfs/english/icil_new_zealand.pdf\&lang=E (dostęp 15 sierpnia 2019 r.) i USA - Comments from the United States On the International Law Commission's Draft Conclusions on The Identification of Customary International Law As Adopted by the Commission in 2016 on First Reading, s. 17, http://legal.un.org/docs/?path=../ilc/ sessions/70/pdfs/english/icil_usa.pdf\&lang=E (dostęp 15 sierpnia 2019 r.).

24 K. Skubiszewski, The Elaboration of General..., s. 33, 40. Por. także Comments by the Government of New Zealand, s. 12 oraz pojęcie instant custom w B. CHenG, United Nations Resolutions on Outer Space: „Instant” International Customary Law?, «Indian Journal of International Law» 5/1965, s. 23-48. 
że doszło do wykrystalizowania się normy międzynarodowego prawa zwyczajowego. Pogląd ten znajduje oparcie zarówno w dotychczasowym orzecznictwie Trybunału, jak i w doktrynie ${ }^{25}$. Niemniej jednak, jak słusznie zauważył K. Skubiszewski, nie ma jasności co do tego, czy wielokrotne powtarzanie tych samych treści w rezolucjach jest mocniejszym dowodem opinio iuris; może być wprost przeciwnie, ponieważ ciągłe powtarzanie tych samych treści może wynikać z tego, że państwa nie przestrzegają postanowień rezolucji ${ }^{26}$.

Po trzecie, na wstępie swoich rozważań MTS wskazał, że będzie musiał zbadać kształt i zakres prawa do samostanowienia, tak jak było ono obecne „w praktyce ONZ” i Wielkiej Brytanii. Ostatecznie jednak Trybunał nie zajął się praktyką żadnego państwa, a jedynie rezolucjami ZO ONZ. Ponadto, w całej opinii doradczej MTS podkreślał rolę ZO ONZ w kształtowaniu zasad dotyczących dekolonizacji ${ }^{27}$. W tym kontekście istotne więc wydaje się zagadnienie włączenia aktów organizacji międzynarodowych $\mathrm{w}$ proces formowania się powszechnego prawa zwyczajowego. Niektórzy komentatorzy zauważają bowiem, że rezolucje są nie tylko formą zsyntezowanej praktyki państ $w^{28}$, ale również stanowią praktykę organizacji międzynarodowej jako takiej ${ }^{29}$. Problematyką włączenia praktyki organizacji międzynarodowych w proces formowania się zwyczaju zajmowała się Komisja Prawa Międzynarodowego (KPM) przy okazji badań nad identyfikacją zwyczaju. Co prawda Komisja wyraźnie

25 Opinia doradcza w sprawie groźby lub użycia broni nuklearnej, par. 70, 73; Dissenting Opinion of Judge Weeramantry, Opinia doradcza w sprawie groźby lub użycia broni nuklearnej, s. 532; Separate Opinion of Vice-President Ammoun, Western Sahara, opinia doradcza z 16 października 1975 r., ICJ Reports 1975, s. 12, s. 99; Dissenting Opinion of Judge Tanaka, South West Africa, wyrok z 18 lipca 1966 r., ICJ Reports 1966, s. 6, s. 292. Por. także Separate Opinion of Judge Dillard..., opinia doradcza w sprawie Western Sahara, s. 121.

26 K. Skubiszewski, The Elaboration of General..., s. 96, 114. Por. także M.H. MenDELSON, op. cit., s. 385-386.

27 Por. opinia doradcza ws. Archipelagu Czagos, par. 163, 168.

28 Tak rezolucje nazywa I. Brownlie, op. cit., s. 19.

29 N. ArajÄRvi, From State-Centricism to Where?: The Formation of (Customary) International Law and Non-State Actors (May 3, 2010), https://ssrn.com/abstract=1599679 (dostęp 15 sierpnia 2019 r.), s. 11; ILA Final Report, s. 19. 
zauważyła, że należy rozróżnić praktykę państw w ramach organizacji międzynarodowej od praktyki organizacji międzynarodowej jako takiej $^{30}$, ale jednocześnie dalsze wywody Komisji, zebrane z różnych dokumentów, są dosyć zawiłe i nie pozwalają na jasne stwierdzenie w jakich okolicznościach praktyka organizacji międzynarodowej, a nie jej państw członkowskich, będzie miała znaczenie dla formowania się zwyczaju ${ }^{31}$. To, co można jednak z pewnością powiedzieć o rozważaniach Komisji to to, że nie wykluczyła ona, iż praktyka organizacji międzynarodowych jako takich może być wzięta pod uwagę przy tworzeniu powszechnych norm prawa międzynarodowego. Mimo, że MTS w sprawie archipelagu Czagos nie nawiązuje do tych poglądów KPM, ani nie bada szczegółowo roli praktyki organizacji międzynarodowych, to można zaryzykować tezę, że Trybunał starał się, nawet jeśli nie stawiając sprawy jasno, wprowadzić rezolucje ZO ONZ jako praktykę/opinio iuris organizacji międzynarodowej do procesu formowania się normy prawa zwyczajowego regulującej prawo do samostanowienia wiążące państwa. Jeśli przyjąć, że taka była intencja MTS, to należy stwierdzić,

$30 \quad$ A/CN.4/682, par. 71.

31 Por. ibidem, par. 72; International Law Commission, Draft conclusions on identification of customary international law, with commentaries, "Yearbook of the International Law Commission» 2.2/2018, s. 130, par. 5-7; A/CN.4/672, par. 44. Por. także C. M. Brölmann, Capturing the Juridical Will of International Organizations, «Amsterdam Law School Legal Studies Research Paper» 9/2019, s. 3-4. 
że nie znajduje ona poparcia przynajmniej wśród części państw ${ }^{32}$ ani doktryny prawa międzynarodowego ${ }^{33}$.

\section{OKOLICZNOŚCI PRZYJĘCIA I TREŚĆ REZOLUCJI ZO ONZ 1514}

Z uwagi na to, że Trybunał przypisał szczególną rolę rezolucji ZO ONZ 1514, należy zastanowić się nad jej faktycznym znaczeniem dla krystalizacji prawa zwyczajowego poprzez analizę okoliczności, w jakich rezolucja ta została przyjęta ${ }^{34}$. Trzeba przy tym zauważyć, że jeden czynnik nie jest decydujący, jeśli chodzi o znaczenie rezolucji jako dowodu istnienia zwyczaju; dopiero kilka czynników łącznie jest rozstrzygających ${ }^{35}$.

32 Por. stanowiska Izraela - UN GA Official Records, Sixth Committee, 22nd meeting, 26 October 2016, A/C.6/71/SR.22, par. 39; Israel's Commentss and Observations, s. 1-2, http://legal.un.org/docs/?path=../ilc/sessions/70/pdfs/english/icil_israel. pdf\&lang=E (dostęp 15 sierpnia 2019 r.), Iranu - UN GA Official Records, Sixth Committee, 23rd meeting, 26 October 2016, A/C.6/71/SR.23, par. 15), Nowej Zelandii (Comments by the Government of New Zealand, s. 9), Stanów Zjednoczonych (Comments from the United States On the International Law Commission's Draft Conclusions..., s. 2, 3) i Rosji (UN GA Official Records, Sixth Committee, 21st meeting, 25 October 2016, A/C.6/71/ SR.21, par. 50). InTERNATIONAL LAW COMmission, Fourth report on identification of customary international law by Michael Wood, Special Rapporteur, A/CN.4/695, par. 19-20. Por. także J. Wouters, P. De Man, op. cit., s. 208; M. Pacholska, New Kids on the Block: International Organizations as Customary Rules Creators, "International Community Law Review» 21/2019, s. 334.

33 G. D. Kyriakopoulos, op. cit., s. 53.

34 O konieczności analizy okoliczności, w jakich rezolucja została przyjęta wspominają m.in. K. Skubiszewski, Forms of Participation of International Organizations in the Lawmaking Processes, «International Organization» 8/1964, s. 791-792; R. Higgins, op. cit., s. 24; A/CN.4/672, par. 76g. Zwracały na to uwagę również Wielka Brytania i USA w czasie postępowania przed MTS w sprawie archipelagu Czagos - Written Statement of the United Kingdom, 27 February 2018, par. 8.31, https:/www.icj-cij.org/files/ case-related/169/169-20180215-WRI-01-00-EN.pdf (dostęp 15 sierpnia 2019 r.); Written Comments from the United States of America on States' Written Replies of September 11, 2018 to the questions posed by Judge Cancado-Trindade, par. 4, https://www.icj-cij.org/ files/case-related/169/169-20180913-OTH-03-00-EN.pdf (dostęp 15 sierpnia 2019 r.).

35 K. Skubiszewski, The Elaboration of General..., s. 99-100. 


\subsection{Głosowanie nad rezolucją}

Jak MTS zauważył, rezolucja 1514 została przyjęta 89 głosami za, żadne państwo nie głosowało przeciw, a 9 wstrzymało się od głosu. Ponadto, Trybunał zastrzegł, że żadne z państw, które wstrzymały się od głosu nie zakwestionowały mocy wiążącej prawa do samostanowienia. Innymi słowy, Trybunał uznał, że nawet rezolucje przyjęte niejednomyślnie mogą odgrywać fundamentalną rolę w krystalizacji norm prawa zwyczajowego. Do takiej tezy można mieć jednak kilka zastrzeżeń.

Po pierwsze, prawdą jest, że komentatorzy, którzy twierdzą, że rezolucje ZO ONZ mogą stanowić przejaw opinio iuris, wskazują, że rezolucje te powinny być przyjęte „jednomyślnie lub niemalże jednomyślnie”36; taki też pogląd zaprezentowała Unia Afrykańska w czasie postępowania o wydanie omawianej opinii doradczej ${ }^{37}$. Powstaje jednak pytanie, czy sytuacja, w której 9 państw na 98 uprawnionych do głosowania (a więc prawie 10\%) wstrzymuje się od głosu nadal może być uznana za bliską jednomyślności ${ }^{38}$.

36 A/CN.4/672, par. 76g; Separate Opinion of Judge Al-Khasawneh, Legal Consequences of the Construction of a Wall in the Occupied Palestinian Territory, opinia doradcza z 2 lipca 2004 r., ICJ Reports 2004, s. 136, par. 2-5; Separate Opinion of Vice-President Ammoun, Legal Consequences for States of the Continued Presence of South Africa in Namibia (South West Africa) notwithstanding Security Council Resolution 276 (1970), opinia doradcza z 21 czerwca 1971 r., ICJ Reports 1971, s. 16, s. 79; M.H. Mendelson, op. cit., s. 360; Dissenting Opinion of Judge Tanaka, s. 291. Inaczej ILA Final Report, s. 64.

37 Written Statement of the African Union, https://www.icj-cij.org/files/caserelated/169/169-20180301-WRI-07-00-EN.pdf (dostęp 15 sierpnia 2019 r.), par. 76.

38 Niemniej jednak, należy też zauważyć, że w sprawie Libyan American Oil Company (LIAMCO) v. The Government of the Libyan Arab Republic, trybunał arbitrażowy, badając legalność środków nacjonalizacyjnych podjętych przez władze Libanu, doszedł do wniosku, że nawet jeśli rezolucje nie stanowią „jednomyślnego źródła prawa” (unanimous source of law), są dowodem ostatnich dominujących trendów dotyczących suwerennych praw państw nad ich zasobami naturalnymi (Libyan American Oil Company (LIAMCO) v. The Government of the Libyan Arab Republic (Petroleum Concessions 16, 17 and 20), 12 April 1977, «International Law Materials» 20/1981, s. 46, 51-53). Por. także Opinia doradcza w sprawie groźby lub użycia broni nuklearnej, par. 71. Por. Written Comments from the United States of America, par. 4. 
Po drugie, fakt, że 9 państw wstrzymujących się od głosu nie zakwestionowało w czasie debaty istnienia prawa do samostanowienia, nie oznacza, że państwa te uznały, że istnieje norma prawa zwyczajowego, która nakłada na nie pewne obowiązki prawne w związku z prawem do samostanowienia narodów kolonialnych. Przykładowo, w czasie debaty nad rezolucją 1514, jedno z państw wstrzymujących się od głosu, Australia, zauważyła, że projekt rezolucji 1514 różni się od KNZ, która ustanawia obowiązki traktatowe i jest dokładnie wypracowana, jak i od Powszechnej Deklaracji Praw Człowieka, która była ostrożnie omawiana w komisji i komitecie, a mimo to nie ma mocy wiążącej. Deklaracja, którą zawiera projekt rezolucji stanowi więc raczej wyraz aspiracji narodów kolonialnych, co do których państwa zgadzają się ${ }^{39}$. Podobną opinię wyraziły Stany Zjednoczone, które podczas postępowania przed MTS w sprawie archipelagu Czagos wskazały, że zarówno w okresie, kiedy ZO ONZ przyjęło rezolucję 1514, jak i pod koniec lat 60., istniały liczne „Wyrazy poparcia moralnego i politycznego dla procesu dekolonizacji”, które wyrażane były także przez USA, ale nie istniała praktyka lub opinio iuris, które świadczyłyby o istnieniu normy prawa zwyczajowego zabraniającej Wielkiej Brytanii ustanowienia Brytyjskiego Terytorium Oceanu Indyjskiego ${ }^{40}$.

\subsection{Debata nad projektem rezolucji 1514}

Jak zostało już wspomniane, o znaczeniu rezolucji dla procesu krystalizowania się zwyczaju świadczy nie tylko wynik głosowania, ale również opinie wyrażane przez przedstawicieli państw w czasie debaty nad projektem rezolucji ${ }^{41}$; potwierdził to zresztą sam MTS w opinii doradczej w sprawie groźby lub użycia broni nuklearnej ${ }^{42}$. W tym miejscu należy więc przyjrzeć się poglądom wygłaszanym przez państwa w czasie dyskusji w ZO ONZ.

39 UN GA Official Records, Fifteenth Session, 933rd meeting, 2 December 1960, A/PV.933, par. 81.

40 Written Comments from the United States of America, par. 3.

${ }^{41}$ T. Ruys, op. cit., s. 50; ILA Final Report, s. 58.

42 Opinia doradcza w sprawie groźby lub użycia broni nuklearnej, par. 70. 
28 listopada 1960 r. 24 państwa Azji i Afryki przedłożyły projekt rezolucji $1514^{43}$, który w sumie poparły 43 państwa ${ }^{44}$. Przedstawiając rezolucję, reprezentant Kambodży na wstępie zaznaczył, że projekt był pisany z „największą troską”, a jego autorzy starali się znaleźć „formuły i rozwiązania”, które mają nadzieję, że zostaną zaakceptowane przez większość delegatów, jeśli nie przez całe ZO ONZ ${ }^{45}$. Nie sposób streścić całej debaty nad projektem rezolucji ${ }^{46}$, ale w tym miejscu należy odnotować punkty wspólne wystąpieniom wszystkich państw i płynące $\mathrm{z}$ nich wnioski.

Po pierwsze, żadne państwo ani nie twierdziło, że z prawa do samostanowienia wynikają dla państw jakiekolwiek obowiązki prawne, ani też nie wypowiedziało się o prawie do samostanowienia jako normie międzynarodowego prawa zwyczajowego. Prawdą jest, że wszystkie państwa podkreślały znaczenie i konieczność przeprowadzenia dekolonizacji, jak i podkreślały prawo narodów kolonialnych do niepodległości i ustanowienia własnego państwa ${ }^{47}$; państwa jednak bardzo rzadko odwoływały się do samego prawa do samostanowienia. Ponadto

43 Te państwa to: Afganistan, Birma, Kambodża, Cejlon, Czad, Cypr, Etiopia, Ghana, Gwinea, Indie, Indonezja, Iran, Irak, Jordania, Liban, Liberia, Libia, Maroko, Nepal, Nigeria, Pakistan, Arabia Saudyjska, Sudan i Togo.

44 Rezolucja została poparta przez Mali, Zjednoczoną Republikę Arabską, Laos, Senegal, Kongo-Brazzaville, Kongo-Leopoldville, Dahomej, Wybrzeże Kości Słoniowej, Górną Voltę, Kamerun, Republikę Środowoafrykańską, Malezję, Madagaskar, Gabon, Filipiny oraz Somalię.

45 UN GA Official Records, Fifteenth Session, 926th Plenary Meeting, 28 November 1960, A/PV.926, par. 11.

46 Swój projekt rezolucji przedłożyli również ZSRR (Declaration on the Grant of Independence to Colonial Countries and Peoples, 23 September 1960, A/4502) i Honduras (UN GA Official Records, Fifteenth Session, 929th meeting, 30 November 1960, A/PV.929, par. 39).

47 Por. np. wypowiedzi Iraku (UN GA Official Records, Fifteenth Session, 926th Plenary Meeting, 28 November 1960, A/PV.926, par. 66, 71), Arabii Saudyjskiej (UN GA Official Records, Fifteenth Session, 927th meeting, 29 November 1960, A/PV.927, par. 82), Polski (UN GA Official Records, Fifteenth Session, 928th meeting, 30 November 1960, A/PV.928, par.74) i Czadu (UN GA Official Records, Fifteenth Session, 931st meeting, 1 December 1960, A/PV.931, par. 87) 
państwa podkreślały „uroczysty” charakter deklaracji ${ }^{48}$ oraz jej znaczenie moralne i polityczne ${ }^{49}$.

Po drugie, wielu uczestników debaty, wskazując na obowiązki państw administrujących w odniesieniu do terytoriów niesamodzielnych, odwoływało się do $\mathrm{KNZ}^{50}$, co jest dowodem na to, że dla państw przyjęcie rezolucji 1514 było sposobem implementacji postanowień KNZ. Z jednej strony świadczy to więc o tym, że dla państw podstawą dekolonizacji nie było prawo zwyczajowe, ale normy zawarte w KNZ; z drugiej strony, z wypowiedzi państw można wywnioskować, że Deklaracja jedynie dopełniała zobowiązania wynikające z KNZ i podkreślała konieczności ich prawidłowej implementacji, ale nie rozwijała ich i nie ustanawiała nowych obowiązków dla państw. Stanowi to argument za politycznym, a nie normatywnym znaczeniem rezolucji 1514.

Po trzecie, z rozważań Trybunału nie wynika jasno, czy przed przyjęciem rezolucji 1514 wykrystalizowała się już norma prawa zwyczajowego dotycząca prawa do samostanowienia, czy dopiero rezolucja 1514 przyczyniła się do powstania takiej normy. Niezależnie od tego, który wariant jest zgodny z intencją Trybunału, należy zauważyć, że omawiając formowanie się normy prawa zwyczajowego, Trybunał zwrócił uwagę jedynie na znaczenie rezolucji ZO ONZ. Tymczasem, w czasie debaty nad rezolucją 1514 państwa równie często co do aktów ONZ, odwoływały się do innych instrumentów, przyjętych przez regionalne organy

48 Np. wypowiedź Jordanii (UN GA Official Records, Fifteenth Session, 930th meeting, 1 December 1960, A/PV.930, par. 46), Indonezji (UN GA Official Records, Fifteenth Session, 936th meeting, 5 December 1960, A/PV.936, par. 26) i Wenezueli (UN GA Official Records, Fifteenth Session, 939th meeting, 7 December 1960, A/PV.939, par. 76).

49 Por. np. wypowiedzi Polski (A/PV.928, par.53), Tunezji (A/PV.929, par. 112) i Pakistanu (A/PV.930, par. 70-73).

50 Por. wypowiedzi USA (UN GA Official Records, Fifteenth Session, 937th meeting, 6 December 1960, A/PV.937, par. 14), Togo (A/PV.936, par. 62), Islandii (Ibidem, par. 11), Wenezueli (A/PV.939, par. 89), Nigerii (UN GA Official Records, Fifteenth Session, 934th meeting, 3 December 1960, A/PV.934, par. 107), Brazylii (Ibidem, par. 125), Nowej Zelandii (UN GA Official Records, Fifteenth Session, 932nd meeting, 2 December 1960, A/PV.932, par. 8), Peru (A/PV.930, par. 85), Jugosławii (A/PV.928, par.83-84), Polski (A/PV.928, par.64-66) i Ghany (A/PV.927, par. 43-44). 
i konferencje. W tym kontekście szczególne znaczenie mają zwłaszcza postanowienia Konferencji Krajów Azji i Afryki z Bandung z 1955 r., oraz rezolucje przyjęte w czasie pierwszej Konferencji Niepodległych Państw Afrykańskich w Akrze w 1958 r. i drugiej Konferencji Niepodległych Państw Afrykańskich w Addis Abebie w 1960 r., jak również rezolucje Pierwszej i Dziesiątej Międzynarodowej Konferencji Państw Amerykańskich oraz normy Konwencji z Montevideo ${ }^{51}$. Jeśli więc Trybunał chciał uzyskać pełen obraz praktyki i opinio iuris państw co do dekolonizacji i prawa do samostanowienia, przy założeniu, że akty organizacji międzynarodowych mają znaczenie w procesie formowania się zwyczaju, powinien wziąć pod uwagę również przynajmniej te $\mathrm{z}$ instrumentów, które wymieniły państwa w czasie debaty jako mające znaczenie dla procesu dekolonizacji. Pomijając analizę tych aktów, Trybunał stworzył wrażenie, że jedynie rezolucje przyjmowane przez organy ONZ (a w szczególności ZO ONZ), a nie w ogóle rezolucje organizacji międzynarodowych, mają znaczenie dla formowania się zwyczaju.

W końcu, należy zwrócić uwagę na kilka szczególnych wypowiedzi państw, które co najmniej podważają tezę o normatywnym charakterze rezolucji 1514. Przykładowo więc, przedstawiciel Panamy powiedział, że jego delegacja zdaje sobie sprawę, że projekt deklaracji, taki jaki został przedłożony przez 43 państwa, nie może nawiązywać do wszystkich praktycznych aspektów osiągnięcia założonych w niej celów; sama deklaracja nie będzie zresztą wystarczająca dla finalizacji dekolonizacji i konieczne będą dalsze prace w tym zakresie na forum $\mathrm{ONZ}^{52}$. Przedstawiciel Nowej Zelandii zauważył, że dyskusji nie jest poddawany traktat, którego postanowienia musiałyby być dokładnie wyważone; „celem deklaracji jest raczej wierne uchwycenie i odbicie ideałów i zasad, które mają powszechne zastosowanie"53. Według przedstawiciela Cejlonu w dyskusji nad projektem rezolucji 1514 nie chodziło

51 Por. wypowiedzi Sudanu (UN GA Official Records, Fifteenth Session, 935th meeting, 5 December 1960, A/PV.935, par. 37), Nepalu (Ibidem, par. 69), Kongo (Brazzaville) (UN GA Official Records, Fifteenth Session, 938th meeting, 6 December 1960, A/PV.938, par. 53), Kambodży (A/PV.926, par. 12) i Panamy (A/PV.938, par. 73-75).

52 A/PV.938, par. 91.

53 A/PV.932, par. 12. 
o koncepcje prawne czy tworzenie prawa; wprost przeciwnie - celem debaty było znalezienie dekolonizacji właściwego miejsca w rozwoju ludzkiego społeczeństwa ${ }^{54}$. Dodał także, że nawet jeśli ZO ONZ nie jest ciałem prawotwórczym, to projekt rezolucji zawiera sankcję, ponieważ stoi za nim „opinia publiczna” ${ }^{5}$. Z wypowiedzi tych wynika więc jednoznacznie, że nawet te państwa, które głosowały za rezolucją, uważały, że ma ona znaczenie polityczne, a nie normatywne, nie jest sankcjonowana prawem, ale normami moralnymi, jak również, że sama rezolucja wyraża nie prawo, a „ideały i zasady”.

\subsection{Treść rezolucji 1514}

Trybunał przypisał rezolucji 1514 szczególne znaczenie z uwagi na to, że ma charakter "normatywny”. Dowodem na tę "normatywność” ma być zarówno głosowanie nad rezolucją i opinio iuris co do jej wiążącego charakteru (które to dowody nie potwierdzają się przy dokładniejszej analizie, jak wskazują poprzednie rozważania), jak i pewne fragmenty rezolucji, zwłaszcza te, które stanowią że „wszystkie ludy mają prawo do samostanowienia”; istnieje „konieczność szybkiego i bezwarunkowego zakończenia kolonializmu we wszystkich jego formach i przejawach" oraz „jakakolwiek próba zaburzenia, częściowego lub całkowitego, jedności państwowej i integralności terytorialnej państwa jest niezgodna z celami i zasadami Karty Narodów Zjednoczonych”.

Po pierwsze, zarówno państwa ${ }^{56}$, jak i nauka prawa międzynarodowego ${ }^{57}$ wskazują, że rezolucje ZO ONZ niekoniecznie muszą przyczyniać się do formowania prawa zwyczajowego, ponieważ decyzja państwa co do tego czy poprzeć czy nie rezolucję może być podjęta z powodów politycznych lub innych i nie wynikać z analizy prawnej rezolucji. Znaczenie ma więc nie to, jak zaszeregowany został głos państwa, czy

54 A/PV.926, par. 135.

55 Ibidem, par. 138.

56 Por. np. stanowisko Wietnamu (A/C.6/71/SR.22, par. 50), Singapuru (Ibidem, par. 40) i USA (Comments from the United States On the International Law Commission's Draft Conclusions..., s. 17).

57 K. Skubiszewski, The Elaboration of General..., s. 95; M. H. Mendelson, op. cit., s. 362 . 
jako głos wstrzymujący się czy „przeciwko”, ale to, jaka była motywacja państwa przy podjęciu decyzji o oddaniu głosu w dany sposób ${ }^{58}$. Dotyczy to zresztą także głosów oddanych „za” rezolucją, które niekoniecznie świadczą o opinio iuris, ponieważ państwa wspierając rezolucję nie muszą tego robić $\mathrm{z}$ intencją kształtowania prawa międzynarodowego, ale wyrażając swoje poparcie dla kwestii politycznych lub chcąc utrzymać konsensus wśród państw ${ }^{59}$. Po drugie, nawet kiedy rezolucja $\mathrm{ZO}$ ONZ zawiera stwierdzenie co do prawa, ZO ONZ może odwoływać się w niej zarówno do istniejących praw i jak i tych postulowanych de lege ferenda. Jeśli więc w rezolucji jest nawet mowa o „prawach” i „obowiązkach”, nie musi to odnosić się do aktualnie wiążących państwa praw i obowiązków ${ }^{60}$. Ponadto, czasami państwa mogą oddać głos za rezolucją właśnie dlatego, że uważają, że nie ma ona skutku prawnego ${ }^{61}$. Po trzecie, K. Skubiszewski zwraca również uwagę, że norma zawarta $\mathrm{w}$ rezolucji musi być tak sformułowana, aby można było ją stosować, bez dalszego rozwijania lub przekształceń. Po czwarte, ten sam Autor zauważa, że aby mówić o mocy normatywnej rezolucji żadne państwo nie może zgłosić zastrzeżeń do rezolucji ${ }^{62}$. Po piąte, na co zwrócił uwagę MTS w sprawie groźby lub użycia broni nuklearnej, jeśli istnieje norma prawa zwyczajowego, do której nawiązuje rezolucja, ZO ONZ może po prostu powołać się wyraźnie na tę normę ${ }^{63}$; jeśli tak nie jest, rodzi to wątpliwości co do mocy obowiązującej danej normy.

Podsumowując, mimo, że nie sposób odmówić rezolucji 1514 znaczenia (nawet jeśli tylko politycznego) w procesie dekolonizacji i rozwoju prawa do samostanowienia, to sama ta rezolucja nie stanowi jednoznacznego dowodu na opinio iuris państw co do kształtu normy prawa

58 T. RuYs, op. cit., s. 50.

59 S.M. Schwebel, The Effect of Resolutions of the U.N. General Assembly on Customary International Law, «American Journal of International Law» 73/1979, s. 302. Teza ta znajduje zresztą potwierdzenie w zapisie debaty nad projektem rezolucji 1514, ponieważ Ghana (A/PV.927, par. 72), Etiopia (A/PV.928, par.18) i Holandia (A/PV.931, par. 45.) wyraziły nadzieję, że rezolucja zostanie przyjęta jednomyślnie.

60 T. Ruys, op. cit., s. 50; ILA Final Report, s. 56.

61 ILA Final Report, s. 58.

62 K. Skubiszewski, The Elaboration of General..., s. 124-125.

63 Opinia doradcza w sprawie groźby lub użycia broni nuklearnej, par. 72. 
zwyczajowego regulującej samostanowienie. Dopiero wsparcie rezolucji 1514 argumentacją odwołującą się do szeroko rozumianej praktyki (i opinio iuris) państw mogłoby stanowić przekonujący dowód co do jej znaczenie w procesie krystalizacji zwyczaju. Wywód Trybunału co do znaczenia normatywnego rezolucji 1514 należy więc uznać za niesatysfakcjonujący.

\section{ZAKOŃCZENIE}

Podsumowując, sposób identyfikacji zwyczaju zastosowany przez MTS w opinii doradczej dotyczącej archipelagu Czagos, znacznie różni się od sposobu badania zwyczaju stosowanego dotychczas przez Trybunał, z uwagi na połączenie następujących czynników: po pierwsze, Trybunał zbadał jedynie opinio iuris, a nie nawiązał w ogóle do praktyki relewantnej dla powstania normy prawa zwyczajowego dotyczącej prawa do samostanowienia. Po drugie, Trybunał swoje rozstrzygnięcie w sprawie oparł na normie prawa zwyczajowego, zidentyfikowanej jedynie na podstawie rezolucji ZO ONZ (ze szczególnym uwzględnieniem rezolucji ZO ONZ 1514). Po trzecie, Trybunał wyraźnie przypisał rezolucjom ZO ONZ szczególne znaczenie, nie jako aktom pochodzącym od państw, ale od organizacji międzynarodowej. Po czwarte, mimo że Trybunał nadał szczególne znaczenie rezolucji 1514, lakonicznie zbadał okoliczności jej przyjęcia. Mimo że dotychczasowa metodologia identyfikacji zwyczaju przez MTS budziła również spore wątpliwości, a w poprzednich orzeczeniach Trybunału można dopatrzeć się podobnych sposobów badania norm prawa zwyczajowego, to takie połączenie, na jakim oparł swoje rozstrzygnięcie MTS ws. archipelagu Czagos, stanowi novum w praktyce Trybunału. Jednocześnie, zarzuty stawiane metodologii Trybunału mogą podważać zasadność jego rozstrzygnięcia, skoro Trybunał niedostatecznie zbadał prawo właściwe dla rozstrzygnięcia sprawy.

Należy więc zwrócić uwagę, że mimo potencjalnej roli opinii doradczej MTS ws. archipelagu Czagos dla oceny legalności procesu dekolonizacji, autorytet rozstrzygnięcia Trybunału pomniejszają zarzuty co 
do sposobu identyfikacji norm prawnych, będących podstawą wydania opinii.

\section{IDENTYFIKACJA MIĘDZYNARODOWEGO PRAWA ZWYCZAJOWEGO W Opinit doradCZEj MiĘDzynarodowego TrybunaŁU SPRAWIEDLIWOŚCI W SPRAWIE ARCHIPELAGU CZAGOS}

\section{Streszczenie}

W lutym 2019 r. Międzynarodowy Trybunał Sprawiedliwości (MTS) wydał opinię doradczą dotyczącą prawnych konsekwencji oddzielenia archipelagu Czagos od Mauritiusa w 1965 r. Celem niniejszego artykułu jest przeanalizowanie metodologii, za pomocą której MTS dokonał identyfikacji norm międzynarodowego prawa zwyczajowego odnoszących się do samostanowienia, które następnie stały się podstawą rozstrzygnięcia Trybunału. Przedmiotem badania będzie więc czwarta część opinii doradczej, „Pytania zadane Trybunałowi przez Zgromadzenia Ogólne". Artykuł opiera się na tezie, że metodologia identyfikacji zwyczaju, wykorzystana przez Trybunał w omawianej opinii doradczej, znacznie różni się od sposobu badania zwyczaju stosowanego dotychczas przez Trybunał, z uwagi na połączenie kilku czynników, w tym w szczególności oparcie identyfikacji zwyczaju wyłącznie o rezolucje Zgromadzenia Ogólnego ONZ. Artykuł został podzielony na cztery części: pierwsza przedstawia zwięźle najważniejsze wątki rozważań Trybunału co do prawa zwyczajowego. W drugiej części porównano dotychczasową metodologię MTS, jeśli chodzi o identyfikację zwyczaju, z rozważaniami z opinii doradczej ws. archipelagu Czagos. W trzeciej części omówiono to, jak Trybunał przedstawił w opinii doradczej sposób formowania się zwyczaju. Czwarta część została natomiast poświęcona rezolucji ZO ONZ 1514.

IDENTIFICATION OF CUSTOMARY INTERNATIONAL LAW IN THE ICJ Advisory Opinion Concerning the Chagos Archipelago 
In February 2019 the ICJ issued an advisory opinion on the Legal Consequences of the Separation of the Chagos Archipelago from Mauritius in 1965. The aim of this article is to analyze the methodology which allowed the ICJ to identify the provisions of the customary international law regulating the right to self-determination, which then became the grounds for the ICJ decision. This study is focused on the fourth part of the advisory opinion, namely "The questions put to the Court by the General Assembly." The article argues that the method the Court used to identify custom for the purposes of this opinion differs significantly from the way it has examined customary international law so far, due to its application of several points, especially the exclusive role it assigns to the resolutions of the UN General Assembly. The article is divided into four parts. The first part briefly discusses the most important points of the ICJ's considerations concerning customary international law. The second part compares the ICJ's methodology used so far with its considerations in the advisory opinion on the Chagos Archipelago. The third part shows how the ICJ presented the formation of custom in this advisory opinion. The fourth part concerns the UN General Assembly's Resolution 1514.

Słowa kluczowe: archipelag Czagos; opinia doradcza; opinio iuris; międzynarodowe prawo zwyczajowe; Międzynarodowy Trybunał Sprawiedliwości; praktyka; prawo do samostanowienia.

Keywords: advisory opinion; the Chagos Archipelago; customary international law; the International Court of Justice; practice; opinio iuris; the right to self-determination.

\section{Bibliografia}

Alston P., Simma B., The Sources of Human Rights Law: Custom, Jus Cogens and General Principles, «Australian Yearbook on International Law» 12/1988-89, s. 82-108.

Alvarez-Jimbnez A., Methods for the Identification of Customary International Law in the International Court of Justice's New Millennium Jurisprudence, «International and Comparative Law Quaterly»60/2011, s. 681-712. 
ArajÄrvi N., From State-Centricism to Where?: The Formation of (Customary) International Law and Non-State Actors (May 3, 2010), https://ssrn.com/ abstract=1599679, s. 1-28.

BAKER R., Legal Recursivity and International Law: Rethinking The Customary Element, «The Dartmouth Law Journal» 14/2016, s. 41-66.

Brölmann C.M., Capturing the Juridical Will of International Organizations, «Amsterdam Law School Legal Studies Research Paper» 9/2019, s. 1-20.

Brownlie I., The Rule of Law in International Affairs: International Law at the Fiftieth Anniversary of the United Nations, Haga 1998

CASSESSE A., WeILER J.H.H., Change and stability in international law-making, Berlin 1988

Charlesworth H.C.M., Customary international law and the Nicaragua case, (1984-7) 11 «Australian Yearbook of International Law» 11/1984-1987, s. 1-32.

D’Amato A., Trashing Customary International Law, «The American Journal of International Law» 81/1987, s. 101-105.

Danilenko G.M., The Theory of International Customary Law, "German Yearbook of International Law» 31/1988, s. 9-47.

De Man P., Wouters J., International organizations as law-makers, [w:] Research Handbook on the Law of International Organizations, red. J. KLABBERS, A. Wallendahl, Cheltenham/Northampton 2011, s. 190-224.

GEIGER R.H., Customary International Law in the Jurisprudence of the International Court of Justice: A Critical Appraisal, [w:] From Bilateralism to Community Interest: Essays in Honourofjudge Bruno Simma, red. U. FASTENRATH et al., Oxford 2011, s. 673-694.

Higgins R., Problems and Process: International Law and How We Use It, Oxford 1995

KIRgIS F.E., Custom on a Sliding Scale, "American Journal of International Law» 81/1987, s. 146-151.

Kyriakopoulos G.D., Formation of International Custom and the Role of Non-State Actors, [w:] Reconceptualising the Rule of Law in Global Governance, Resources, Investment and Trade, red. Ph. PAzARtzis, M. Gavouneli, Oxford 2016, s. 43-58.

Mendelson M.H., The Formation of Customary International Law, «Recueil de cours» 272/1998

PaCHolska M., New Kids on the Block: International Organizations as Customary Rules Creators, «International Community Law Review» 21/2019, s. 325-343. 
RoBerts A., Traditional and Modern Approaches to Customary International Law: A Reconciliation, «American Journal of International Law» 95/2001, s. $757-791$.

RuYs T., "Armed attack" and Article 51 of the UN Charter: customary law and practice, Cambridge 2010

SCHLÜTter B., Developments in Customary International Law, Leiden/Boston 2010

Schwebel S.M., The Effect of Resolutions of the U.N. General Assembly on Customary International Law, «Proceedings of the American Society of International Law» 73/1979, p. 301-309.

Skubiszewsin K., Elements of custom and the Hague Court, «Zeitschrift für ausländisches öffentliches Recht und Völkerrecht» 31/1971, s. 810-545.

Skubiszewski K., Forms of Participation of International Organizations in the Lawmaking Processes, «International Organization» 8/1964, s. 790-805.

Skubiszewski K., The Elaboration of General Multilateral Conventions and of Non-Contractual Instruments Having a Normative Function or Objective, «Institute of International Law Yearbook» 61.I/1985, Session of Helsinki, s. 29-358.

TALmon S., Determining Customary International Law: The ICJ's Methodology between Induction, Deduction and Assertion, «The European Journal of International Law» 26.2/2015, s. 417-443.

Tomka P., Custom and the International Court of Justice, «Law \& Practice of International Courts \& Tribunals» 12/2013, s. 195-216. 